\title{
Photoacoustic Characterization of Natural Mineral Pyrite $\left(\mathrm{FeS}_{2}\right)$
}

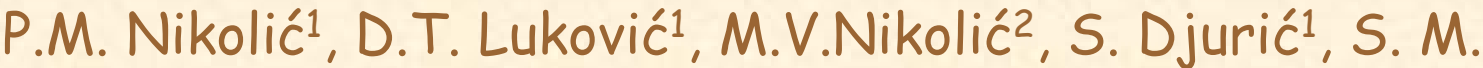 \\ Savić ${ }^{1}$, A. M. Milovanović ${ }^{3}$, S. R. Đukić ${ }^{3}$, B. Stamenović ${ }^{1}$
}

${ }^{1}$ Institute of Technical Sciences of SASA, Knez-Mihailova 35/IV, 11000 Belgrade, Serbia and Montenegro

${ }^{2}$ Center for Multidisciplinary Studies, University of Belgrade, Kneza Viseslava 1a, 11000 Belgrade, Serbia and Montenegro

${ }^{3}$ Technical Faculty of Čačak, University of Kragujevac, Cara Dušana 34, 32000 Čačak, Serbia

\section{Introduction}

Iron pyrite $\left(\mathrm{FeS}_{2}\right)$ is a natural mineral with a cubic elementary cell $\mathrm{Pa} \overline{3}$ and lattice constant $a=5.416 \AA$ [1]. Pyrite has potential for use in lithium batteries [2] and for thin solar cells [3]. It's electronic and optical properties were recently studied [4].

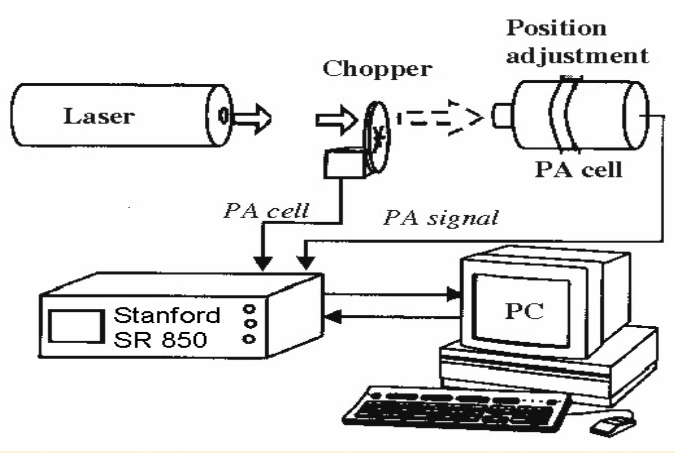

PA measuring equipment

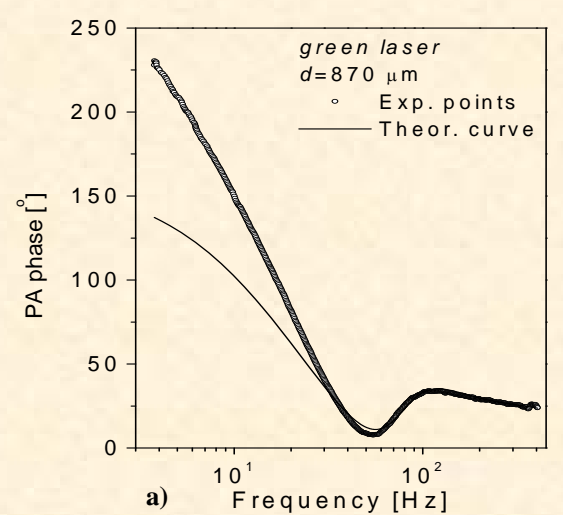

Fig. 1. Experimental and theoretical (full line) PA amplitude (a) and phase (b) diagrams for the pyrite sample $870 \mu \mathrm{m}$ thick

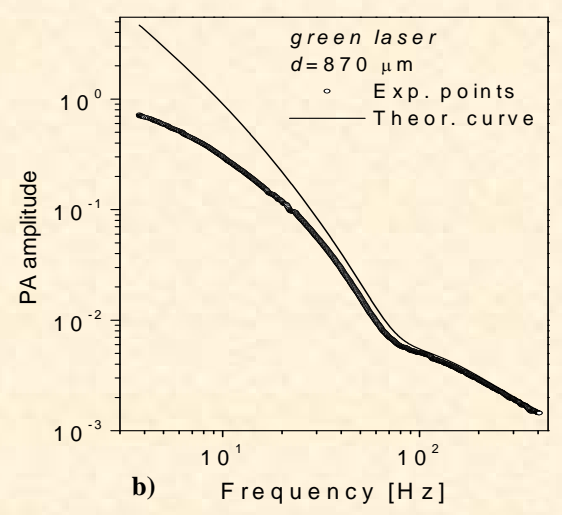

b) Frequency $[\mathrm{Hz}]$

\section{Experimental}

Single crystal p-type samples of this mineral from the Novo Brdo mine in Serbia was cut parallel to the [210] plane. The samples were disc shaped with a diameter about $9 \mathrm{~mm}$ and thickness less than $1 \mathrm{~mm}$. Photoacoustic (PA) amplitude and phase spectra versus the modulation frequency were measured using a transmission detection configuration with red and green lasers. In Fig.1 the experimental results obtained with a green laser are given with circles. The theoretical curve is given with a full line. It was analysed using a modified Rosencwaig- Gersho thermal piston model [5]. The experimental and theoretical diagrams are different in the frequency range below about $40 \mathrm{~Hz}$ where the electret microphone sensitivity is decreased.

The calculated parameter values are given in Table 1 where $D_{T}$ is thermal diffusivity, $\tau$ excess carrier lifetime, $D$ the diffusion coefficient of the minority carriers, $\alpha$ - the optical absorption coefficient, $s_{g}$ and $s_{b}$ are the front and rear surface recombination velocities. The value for the minority free carrier mobility is $1080 \mathrm{~cm}^{2} / \mathrm{Vs}$ that is much higher than the literature value of $230 \mathrm{~cm}^{2} / \mathrm{Vs}$ [6] obtained for polycrystalline samples.

Table 1. The values of parameters obtained by the fitting procedure for PA spectra of pyrite using the green laser

\begin{tabular}{|c|c|c|c|c|c|c|c|}
\hline $\begin{array}{c}d \\
{[\mu \mathrm{m}]}\end{array}$ & $\begin{array}{c}D \\
{\left[\mathrm{~m}^{2} / \mathrm{s}\right]}\end{array}$ & $\begin{array}{c}D_{T} \\
{\left[\mathrm{~m}^{2} / \mathrm{s}\right]}\end{array}$ & $\begin{array}{c}\tau \\
{[\mu \mathrm{s}]}\end{array}$ & $\begin{array}{c}\alpha \\
{\left[\mathrm{m}^{-1}\right]}\end{array}$ & $\begin{array}{c}\mathrm{s}_{b} \\
{[\mathrm{~m} / \mathrm{s}]}\end{array}$ & $\begin{array}{c}\mathrm{s}_{g} \\
{[\mathrm{~m} / \mathrm{s}]}\end{array}$ & $\begin{array}{c}\mu_{n} \\
{\left[\mathrm{~cm}^{2} / \mathrm{vs}\right]}\end{array}$ \\
\hline 870 & $0.27 \times 10^{-2}$ & $0.65 \times 10^{-5}$ & 19 & 9520 & 11.2 & 115 & 1080 \\
\hline
\end{tabular}

The authors would like to thank Mr Branislav Milosavljevic from the Institute of Copper, Bor for mass spectroscopy measurements.

\section{References}

1. K. C. Prince, M. Matteucci, K. Kuepper, S. G. Chiuzbaian, S. Bartkowski, M. Neumann, Phys. Rev. B 71: 085102 (2005).

2. Y. Shao-Horn, Q. C. Horn, Electrochem. Acta 46: 2613 (2001).

3. I. J. Ferrer, J. R. Ares, C. R. Sanchez, Solar Energy Materials and Solar Cells 76: 183 (2003).

4. G. U. von Oertzen, R. T. Jones, A. R. Gerson, Phys. Chem. Minerals 32: 255 (2005).

5. P. M. Nikolic, S. S. Vujatovic, D. M. Todorovic, M. B. Miletic, A. Golubovic, A. I. Bojicic, F. Kermendi, K. T. Radulovic, J. Elazar, Jpn. J. Appl. Phys 36: 35 (1997).

6. T.A. Bither, R.J. Bouchard, W.H. Cloud, P.C. Donohue, W.J. Siemons, Inorg. Chem. 7: 2208 (1968). 